\title{
The Growth of Indonesian Aesthetic Value of Kriya (Handicrafts) in the 21st Century
}

\author{
Dheni Harmaen (Corresponding author) \\ University of Pasundan, Country Indonesia \\ E-mail: hilmanmap@gmail.com
}

Received: January 23, 2016 Accepted: February 29, 2016 Published: March 1, 2016

doi: 10.5296/jsss.v3i2.8586 URL: http://dx.doi.org/10.5296/jsss.v3i2.8586

\begin{abstract}
The development of aesthetic values in the handicraft have been changing in terms of function, shape, appearance and even in terms of its significance, the changes will appear also to changes in the aesthetic value of a work of craft, because the essence of the aesthetic is beauty. In terms of language, the term kriya used in Indonesian language derived from Sanskrit, the word Kriya, when transferred to the Java language has a meaning work or action, and in particular the work related to religious ceremonies. Aesthetic value in a craft covered elements of line, shape, texture, color, composition and so on. The growth of aesthetic value to the craft woven eve of the 21 st century can be traced starting from animist civilizations, until the civilization Ekotek Dynamic information (science and technology), or what we call the global community that positions the craft as a commodity. This development is an inter-linkages which always affect one aspect with other aspects including its aesthetic elements. Art craft is one branch or twig arts is undergoing a transformation, both form and function that are often lengthy conversations or discussions, regarding the status and position in the art developments in Indonesia. The development of craft capable of evolving to position itself in three directions, each of which has different interests, they are: 1) preservation oriented, 2) development to economic or commercial interests (craft industry) oriented, and 3) personal expression (artistic achievement) oriented.
\end{abstract}

Keywords: Values, Kriya, Aesthetics, Development

\section{Introduction}

\subsection{The Overview of Kria}

The term review of the kriya has been put forward by the Japanese kriyawan Soetsu Yanagi (1972) that the craft can be matched as a result of human work that is used in everyday life, adding that different craft to fine art, which in the making aim to be seen. Kria more just to be 
seen, but also bring aspects of the order on each object. Consequently, there is emphasis on the word 'order' that stand in craft, even to this aspect relates to the beauty contained in the craft. A beautiful craft work brings function aspect to be born with it, a craft work without having aspects of function, according to him, the beauty itself is not found in the work of that craft.

The definition is generally described further in seminars of kriya arts and crafts, hosted by G. Sidhartha Soegijo (1995) that the craft as a way of doing traditional things, look at these objects we know and admire, the precision, hand skills, and skills to master the material used as the basis of embodiment. Embodiments in accordance with the potential of advanced materials and meticulously realized that the structural integrity of the material and the beauty. Thus, crafts is a traditional way to produce kriya objects, and it is called beautiful because of its form an art craft that resulted from our own nation.

From the above explanation that the objects of craft known to the public today is a traditional craft passed down through generations of our ancestors and contains the beauty aspect. The term kria is relatively used in Indonesian recently, so it causes many questions and confusion, but also can cause over-imitating in using the term. This is possible because the term is less or not be clear about the meaning, so that the term kriya is often identified with the craft.

In terms of language, Soedyawati (2009) argues in her paper that the word kria used in the Indonesian language derived from Sanskrit, the word Kriya, when transferred to the Javanese language has a meaning of work or action, and in particular the work related to religious ceremonies. In Hindu religious books called kitab agama describes one of its four parts is a craft. As for the three other sections in the book of the religion of Jhana, Yoga, and Carya. Jhana describes the concepts of truth of religions. Yoga represents the physical and mental action method to unite ourselves with the highest truth. Carya explains about good behavior in everyday life, while kria describes candidan statues of gods that unites themselves with the ultimate truth.

From the description above, it can be concluded that in the beginning, kria related to the context of Hindu art. Artistic activities organized via the kria. It is not art that has unlimited individual freedom, but with certain limits directed by the concept of religious truth that can be accepted by the traditions of the community at that time.

The Java community has a history of dualism culture. Dualism here means:

1) Budaya Agung. It is the culture spread in the great tradition of developing within the walls of the palace, among the aristocracy or elite feudal agrarian society.

2) Budaya Alit. The culture expanded beyond the walls of the palace, among the rural people or kawula alit.

From these two traditions, it can be ensured that there are a dividing line between the two regarding lifestyle with its rules. Division here does not mean contradiction, but rather a pattern of harmony and a-must-balance between one leads and those who are led, as a fairness in Javanese culture as implied in the concept of servant relationship kawula gusti and kawula alit (Kuntowijoyo, 1987).

From inside the walls of the palace known as the term kriya. The practice craft intended for the production of functional artifacts, ceremonial, and spiritual, honor the symbolic values of 
the position of the center of government palaces of Java. Craft artists in the past have a high position with a master's degree. The work of the masters of this eventually gave birth to classical Javanese art which is considered to have a high value called adiluhung (Asmujo, 2000). For the production of artifacts in a small community outside the walls of the palace, according to Gustami Sp. (1991), is mentioned as a craft, such as the maker of hoes, machetes, mortar, baskets and others, which in its manufacture more importance in terms of usability or convenience only. From both these instances cited, may be used as a comparison, that there is a difference between kriya with the craft.

The existence of a hierarchical distinction between the production of artifacts in the palace and the people's life is under a historical fact. But, quite dubious about the use of the term "craft" in the past, given the newly popular term used after independence and is not present in the treasures of the old Javanese language.

The words "corporate art" in Dutch, kunstnijverheid, are likely to be the origin of the term of craft, the problem is that the opponent laziness, as a coincidence ijver (almost like Nijver) means craft. So, busyness nmely nijverheid was considered as craft, the goods results are crafting activities (Sudjoko, 1991).

From the above description, it can be concluded that the emergence of the term kriya is associated with Hindu religious ceremonies, while the term craft deals with the production and / or re-production of art objects whose activities were based on commercial-economic interests.

\subsection{The Development of Kriya}

The existence of the craft in the past has contributed outstandingly in meeting the needs of the artistic man in his day. The works presented later became part of the object of study because it had become objects of art and culture in tracking the surrounding civilization. But, how about the development of the craft today? The answer would be initiated by revealing the background and its re-emergence of the term kriya works that seemed new in contrast to the works of the past kriya.

The word "kriya" was recently used in Indonesian; The word is derived from Sanskrit dictionary Wojowasito (1988) is given meaning; employment; deeds; and in old dictionaries Winter interpreted as damel, (making). Furthermore, Soedarso Sp. (1990) also said, when the Department of Kriya Art was born in ASRI (now ISBI) in Yogyakarta in 1950, this term has not used yet and is named Department of Art Carpentry Section. Art Craft had also been used for naming this department, but because both art carpentry and craft deemed unrepresentative and misleading connotations, the department was named Kriya Art.

Lawsuit about the words "art", as described above, is possibly due to the attitude of the deification of the expression of the other branches of the art at that time, which align themselves with Western art. As well known by the public art, especially in college that the concepts of Western art mostly expressed, the cluster mindset of Western Art mostly classified as art (seni rupa) are generally only painting and sculpture only (Sudjoko, 1991).

Modern culture characterized by industrialization movement in all areas was unquestioned longer bear the presence of new values and give birth to a new institution for the community supporters. Modernization with its logical impact gives the change patterns and behaviors 
that have long established firmly in tradition. This values changing, in the end, eventually determine the direction of the arts development, particularly kriya.

Further Sudjoko explained that the development of kriya in Indonesia showed that the kriya and its changes occur is in accordance with the spirit of its time. When the human civilization at the level of animist and dynamic (stages I and II), the product of crafts relates to the physical and spiritual life according to the faith community supporters. At the level of society of Theocentric / religious (stage III), there is a change of nature thought multhiteisme towards a single level, so manifested symbolic artistic skill guides the need for the kriya at that time. In the growth of industrial development (phase IV and V) kriya becomes a commodity to a service product that is guided by the progress of science and technology, the kriya work produced in that time is service-oriented, in this case is the market. Finally, in a recent time (stage VI) which is the global era, the presence of kriya used as a service product to be a commodity trade.

Kriya art is an undergoing branch or twig art, both form and function transformation, so it is often a long conversation or interesting discussion, regarding the status and position in the art developments in Indonesia (Soedarso, 1990). Innovation in the kriya are constantly running, it is mainly done by young or prospective kriyawan-kriyawan (kriya artist) who still has potential passion in exploring and developing the kriya in many arable fields, for example, weaving craft of various kinds of plants, woodwork, ceramic craft and textile craft (in this case especially batik). From these areas is able to flourish simultaneously in three directions, each of which has different interests. They are: 1) conservation -oriented, 2) development to economic or commercial interests (craft industry) oriented. 3) to the interests of personal expression (artistic achievement) oriented. These three things can be explained as follows:

1) Preservation of Art Craft

Preservation means to sustain the existence of craft art of the past in the form of theoretical and practical, by absorbing the knowledge craft art that scattered in various areas, through literature and / or field study to the area which is the source of the study, whereas practically usually done in the form of basic practices for mastering techniques of making works of past craft art. Thus, in the next stage, the candidates become the conservers of kriya art.

The absorption of knowledge and technical skills of the past was certainly not entirely done by the kriyawan candidates, but leads to sorting their respective fields that they are interested in, considering the kriya has many areas of arable land. The continuation stage of the kriyawan candidates are expected to develop kriya in his art world.

2) The Development of Functional Objects of Kriya Art

The development in the form of the creation of functional objects (both practical and non-practical). With the principles of functional design that is comfortable. The development is focused on utilization of primitive arts ornaments, traditional, and classic (with the exclusion of its philosophical foundation), processed and presented in harmony or in the form of artistic entirety. As to the creation of non-practical functional objects essentially is the same as the creation of practical ones. It is just that one wears considerations direct physical usability, while the other one wearing other considerations in accordance with the understanding. 
3) The development of Kriya Art in the creation of works of Kriya-Expression

Along with the times, it turns out the ideals of human art. When in the past one creates works of craft art based on the expertise of art for a particular purpose, now man also intends to create work of art that in accordance to the spirit of recent time, that is an art that stands alone for the purpose of personal satisfaction. This sort of motivation that lies behind the development of direction and development of kriya art in presenting the works of kriya-expression. The developments in this field have the flexibility and freedom in line with the innovative and creative capabilities and the strength or depth of expression of each (candidate) kriyawan. As for the media used mostly falls on the choice of materials that are already known, as long as it fits with mastered or preferred technique. The presence of of artistic- achievements-oriented kriya work can be seen through the exhibitions that are often held. To name the work of craft separated in terms of function alias fine art works is called the kriya work of art. This term is significantly raised in Yogyakarta arts festival III FKY III, precisely in 1991.

\section{The Nature of Aesthetics Value}

Aesthetics can be regarded as a theory of beauty or art. Aesthetic values associated with beautiful, ugly or not beautiful. Aesthetic value means the value of beauty. Baumgarten (1985) explains that beauty can be given widely / narrowly meaning, and pure aesthetics is:

1) Broadly, the beauty contains the idea of goodness, any abstract and the concrete thing is containing the idea of goodness is beautiful. The beauty in the broad sense includes many things, such as the character of a beautiful, beautiful law, the science of the beautiful and wonderful virtues.

2) In a narrow meaning, beauty is limited to the scope of visual perception (shape and color)

3) On a purely aesthetic, beauty concerns on the aesthetic experience of a person in relation to everything that taken through sight, hearing, touch and feeling, that everything can lead to the perception (assumption) is wonderful.

According to (Effendy, 1993), the term of aesthetics derived from the Latin aestheticus or Greek aestheticos derived from the word meaning aithe of feel. Aesthetics can be defined as an arrangement of a part of something that contains the pattern. The pattern that serves to unite the parts containing the alignment of the elements, to rise the beauty.

There are a variety of classical teachings about aesthetics we need to take as a basis in this article. Plato's view of beauty can be divided into two, unity about the world of ideas and beautiful and the source of all beauty is the most simple, 'simple' is the shape and size of which was not given further restrictions based on something more simple. Therefore, such beauty is disaggregated. Such beauty can only be demonstrated, for example red, green, etc. Nevertheless, the compound also can be experienced as something beautiful when it is arranged in harmony based on really simple thing. This second view has privileges because they do not escape from the sensory experience that is a constitutive element of the aesthetic experience and the beauty in the everyday sense.

The value of beauty in some areas basically have in common. The background of different creativity and cultures led the different understanding of the beauty from every nation, even though the spirit, ideals, values and orientation remains the same. Esthetic in the end is 
something relative. To know the sense of aesthetic, especially on the kriya, Yudoseputro (199) argues in the book seni kerajinan Indonesia that as works of art, craft objects must display aesthetic value or the value of the beauty of form, while for the applied arts, aesthetic value craft can not be separated from the value of the point. Unlike the works of fine art, where aesthetic value appears on the form as a medium of expression of the artist freely without taking into account their useful function. As in art, craft aesthetic value also determines the quality of the art. The difference is that in the work of the fine arts the ability or skills in the craft art is not only an attempt to exploit the materials but also to create a form that answers its useful functions.

From the above elaboration, it can be concluded that the beauty value of crafts (kriya) as applied art will rise when assissted with the function value of each object, in contrast to fine art where aesthetic value appears as a form of expression media of the artist freely regardless of its useful function. The definitions described above includes the definition of aesthetic value based on the idea.

\subsection{Art Aesthetic Value}

Art is one of the elements of culture that grows and develops in parallel with the development of human as a composer and connoisseur of art. While culture is the result of thought, work and all the activities that reflect pure instinct (Yudosaputro, 1999).

Art has aesthetic value (beautiful) preferred by humans and contains the ideas expressed in the form or activities as a symbol. Art can give pleasure as a result of the reflection of the feelings from the stimulus that we receive. The enjoyment of art is not the physical pleasure, but mental pleasure that appears when we catch and feel symbols of aesthetics of art composer. In this case the art has a spiritual value. The depth and complexity of the art led experts to make the definition of art to simplify our approach in understanding and assessing art. The emerging concept varies according to the background of the understanding, appreciation, and the views of the experts of the art. Furthermore, Yudosaputro mentions the definitions of art from the experts, they are:

1) Encyclopedia of Indonesia, the art is the creation of objects or anything that because of the beauty of its shape, people love to see or hear.

2) Ki Hajar Dewantara, Art is a human action (composer) arising from feelings and are beautiful, so it can move the soul and human feelings (receiver).

3) Achdiat Kartamihardja, art is a human spiritual activity that reflects reality into a masterpiece. Form and content has the power to evoke a certain inner experience of the recipient.

4) Aristotle, art is an imitation of natural forms with creativity and ideas of the artist to make it more beautiful.

5) Leo Tolstoy, art is a conscious human activity (composer) with intermediary of particular concrete signs to convey the feelings that have been felt to others (receiver) so come to feel the feelings as the composer naturally.

6) Schopenhauer, art is an attempt to create other forms of fun. Although music is the most abstract art, but everyone loves it.

7) Thomas Munro, Art is a man-made media (composer) to cause thevpsychological effects 
on other human beings (receiver). These effects include any response, such as observation, recognition, rational or emotional imagination.

While for the aesthetics of art as being outside the scope of logic or ethics, the definitions according to the experts are as follows.

1) AlGhazali, the beauty of an object lies in the manifestation of the perfection of characteristic of the object and coupled with the existence of the soul or spirit in it.

2) Alexander Baumgarten, the beauty of it is seen as a unity which is the regular arrangement of the parts that have a close relationship with one another as a whole.

3) Herbert Read, beauty is a unified formal relationship from the observation that cause the pleasure.

4) Immanuel Kant, beauty viewed from two sides is objective. Beauty is the harmony of an object toward the purpose they contain, as far as the object is not be seen from subjective function.

5) Zulser, beauty is something that is good and can foster a sense of morality.

The adherents of the objective theory place the aesthetics in more mainstream concepts, mindset, or logical reason why something is said to be beautiful. However, the adherents of the subjective theory put the inner beauty of the artwork personally so that the audience can not give a reason why something is said to be beautiful. The beauty of art is an expression of beauty, creative artists. Thus, the natural scenery is not the beauty of art.

In art as creativity, humans have the advantage of a mind, heart, emotion, passion, and the ability to create something. Any attempts at using the mind to create something (the creation of) new, good, real or abstract is called creativity. The process of artistic creation has a special characteristic, such as below:

1) Unique. Unique means being different from the others, people never made before whether in terms of ideas, techniques, or media. It would be nice if your artwork is the result of your own creations, not follow the example of the existing ones. Other works can be used as a trigger ideas. Develop the idea into something unique and new. Thus, your creativity will be honed.

2) Individual (private), meaning that it has the specificity characteristic of the artist, different with other artists because of different views, appreciation, experience and techniques in creating works of art. Compare your work with work friends. The object that is used as a trigger for the idea that art can be the same. But because of the view, appreciation, experience, and different techniques, the result would be different.

3) Expressive, works of art is the result of the outpouring of the mental form from the elaboration of ideas, reflections, feelings, or thoughts of artists. Art without the outpouring of heart will seem dry and can not touch the feeling to enjoy it.

4) Universal, works of art can be enjoyed by all levels of society, the nation, and generation because of the aesthetic and artistic sense similarities.

5) Survival (durable), the value of art in an art work can be enjoyed all time because of its aesthetic value is consistent. For example, a relic of ancient works of art, we can still enjoy it today. 
6) Aesthetics or values of beauty in art and design, the difference lies on the aesthetic to be appreciated. The aesthetics in the design is part of a product function.

Hence, the beauty of art is an expression of beauty, creative artists. Thus, the natural scenery is not the beauty of art, art is said to be beautiful if it contains elements, as well as the ways to understand the certain characteristics as described above.

\subsection{Aesthetic Value Design}

In the design theory known as the form follow function principle, which is form follows function design. In addition to fulfilling the function, there are three aspects of design that must be met if a product design wants to be considered successful, they are: aspects of product design should have a security aspect (safety), comfort (ergonomics) and beauty (aesthetics) (Agus, 2005).

1) The security aspects means a product design does not harm the user. The ergonomic aspects means of a product design proportions fit when worn. Aspects of beauty means a product designed to be unsightly. A chair must be strong so as not to collapse when occupied, then this relates to security.

2) The seat should be proportional to the size of a human, so it feels fitting used is not too high or too low, not too big or too small, inconvenient when occupied. It deals with the problem of visual ergonomy. Visually, the shape and color of the chair should be interesting.

3) Aesthetics in the manufacture of chairs, armchairs designed as an useful object that is to sit. Unlike the painting. Painting on the wall, to be appreciated. Appreciated means understood and enjoyed. Painting is understood to require intellect to be able to appreciate the works of art, so they can enjoy it. One can not appreciate. The capture of Prince Diponegoro painting well if he does not have the knowledge (intellect) about the history of the character, even further if it does not know about the history of the war in Indonesia. Agus explained (2002) also that the aesthetics of the design and art can be described that seat, flip-flops, lamp shades, and hats scouts are some examples of useful products. Each product have a function in everyday life. If these items are too often used and damaged, must be replaced with new ones. Broken wooden chair can be used as fuel for cooking, sandal strap broke can be put in the trash. Scout faded cap can be used as a table cloth to clean the spillage of meatball soup.

The design products are used when they still meet the last three elements, namely security (safety), comfort (ergonomics) and beauty (aesthetics). If one element was missing, the product design will switch the function of the object to be useless things. Product design outdated can also enter a wastebasket, or recycled into other products. But paintings are different with chairs. Painting is eternal like a series of aphorisms, he could not have out-of-dated fashion design. Raden Saleh's paintings which have hundreds of years although it looks dull, he will still be appreciated. The value of a painting lies in aspects or ideas, rather than on the physical alone.

Designs are created to meet the utility function, while the art is to meet the personal expression and to express ideas (notion) The design is practical, while art is ideological.

Absurdity of all the artwork in the name of freedom and the absurdity of the art, as all can be claimed as a work of art. When the notion of art began to deviate, confusion among the general public bursts. Many people are not familiar with the artwork. Is it true that every 
human expression can be considered works of art? Although ugly, unsightly, it is not pleasant to hear and feel uncomfortable? The recent phenomenon appears in arbitrary use of the term of art. As if anyone could claim to be the creator of the artwork. Art becomes absurd without clear boundaries.

Thus, Art can differentiate from Design, the design realization must fulfill certain functions. Beside the functional, there are three basic principles that must be met in order to be regarded as a good design, they are: security, comfort and beauty. Works of art should express the particular manifestations of idea (notion). In addition to aspects of the idea, the artwork should also have three basic principles of the design is to be regarded as a great work of art. Works of art should be safe, should not harm the safety of people in the workart. Workart should also be good on its appearance in a room, its presence in a place not disturbing. Workart should also be beautiful, contain elements of aesthetics. Despite having a number of similarities, design and the arts have an essential difference. Designs are created to meet the utility function, while the art is to meet the personal expression and to express ideas (notion) The design is practical, while art is ideological.

\subsection{Aesthetic value of Kriya}

The essence of aesthetic is value, elaborating further on the aesthetic means to discuss the values of beauty. In the end, the sense of aesthetic is dealt with the philosophy of beauty which includes the totality of life, that can move the human spirit and apply to what are perceived in line with the conception of life at that time. Aristotle wisely entered into symbols of beauty that can be encountered on beautiful goods, literature, crafts, music or great buildings.

The value of beauty in some areas basically have in common. The background of different creativity and cultures led the different understanding of the beauty from every nation, even though the spirit, ideals, values and orientation remains the same. Esthetic in the end is something relative. To know the sense of aesthetic, especially on the kriya, Yudoseputro (199) argues in the book seni kerajinan Indonesia that as works of art, craft objects must display aesthetic value or the value of the beauty of form, while for the applied arts, aesthetic value craft can not be separated from the value of the point. Unlike the works of fine art, where aesthetic value appears on the form as a medium of expression of the artist freely without taking into account their useful function. As in art, craft aesthetic value also determines the quality of the art. The difference is that in the work of the fine arts the ability or skills in the craft art is not only an attempt to exploit the materials but also to create a form that answers its useful functions.

From the above elaboration, it can be concluded that the beauty value of crafts (Kriya) as applied art will rise when assisted with the function value of each object, in contrast to fine art where aesthetic value appears as a form of expression media of the artist freely regardless of its useful function. The definitions described above include the definition of aesthetic value based on the idea.

Furthermore, Yudoseputro (2003) describes the visual-based aesthetic value that when people look at or enjoy a work of art, unconsciously he saw a line, shape, texture, color. Works of art appears completely which gives the message and a certain impression to the 


\section{I Macrothink}

beholders. In the early stages, people are interested in the function of wear on the cup. When people are better trained of art appreciation power, then one is not only interested solely in the function of these craft objects, but began to observe, appreciate the elements of its physical. One is interested also on making technical and quality character of materials. Then one will be interested in the form and decoration, can start judging from its color, texture or design of crafts. From the appreciation of the experience, then people will be trained to live the essence of line, shape, color, texture and design. Aesthetic value by means of visual assessment of the aesthetic elements relating to color, shape, texture, line, design, composition, and so forth.

Timbul Haryono (2002) argues that kriya art is a branch of art that emphasizes on a high skill in the process. Craft art comes from the word "Kr" (Sanskrit language), which means working, from the root of the word then becomes the work, skill and labor. In a special meaning, it is doing something to generate valuable objects or art objects, listening to the opinion of Prof. SP. Gustami who outlines that kriya art is a precious cultural heritage noble art, which at the time of the Java kingdom got a higher level than the craft. Kriya art is consumed by the nobility and the elite society while the craft is supported by the general public or the kawula alit-people who live outside the walls of the palace. Kriya art is seen as a unique and high quality art because it is supported by a high craftmanship, while the craft is deemed rude and seem incomplete. Distinguish keris with a good knife processes, materials, or the ability of the manufacturer.

From some of the opinions that have been discussed previously, it is explained that the initial form of craft art is intended as a useable arts (applied). Kriya art practice was originally intended to make functional items, both intended for religious purposes or practical needs in human life such as; household utensils. The examples can be seen in the form of artifacts and tools ax in the stone age as well as relics from the era of bronze metal in the form of nekara, moko, Candrasa, ax, vessel, to jewelry such as; bracelets, necklaces, rings. These objects are used as jewelry, ceremonial procession of traditional rituals (tribe) and the ritual nature of trust as respect for the ancestors. Thus the ratio of the value of aesthetics in art, design and craft can be described in the table below: 
Table 1. The ratio of the value of aesthetics in art, design and Kriya

\begin{tabular}{|c|c|c|c|c|}
\hline No. & Description & Art Aesthetic Value & Aesthetic & Kriya Aesthetic Value \\
\hline 1. & Features & $\begin{array}{ll}\text { Emphasized } & \text { to } \\
\text { express } & \text { the } \\
\text { particular ideas. } & \end{array}$ & $\begin{array}{l}\text { Emphasized to } \\
\text { contain the safety, } \\
\text { ergonomic, and } \\
\text { aesthetics aspects. }\end{array}$ & $\begin{array}{l}\text { Emphasized to contain } \\
\text { the artist's skill quality } \\
\text { with the aspect of color, } \\
\text { material, intimacy, } \\
\text { texture, line, shape, } \\
\text { composition, etc. }\end{array}$ \\
\hline 2. & Function & To be appreciated & To be functioned & $\begin{array}{l}\text { to be used and to decorate } \\
\text { Fulfilling personal }\end{array}$ \\
\hline 3 & Creation & $\begin{array}{l}\text { Fulfilling personal } \\
\text { expression. }\end{array}$ & $\begin{array}{l}\text { Fulfilling functional } \\
\text { object. }\end{array}$ & $\begin{array}{l}\text { expression and functional } \\
\text { object. }\end{array}$ \\
\hline
\end{tabular}

There is the relevance of the aesthetic value or values of beauty in art and design. The difference is aesthetic in art to be appreciated, while the aesthetics in the design is part of a function of a product, while the craft art can be used both.

\section{Closing}

Kriya existed and evolved since animist culture to civilization of Ekotek with information (science and technology), or what we call the global community that positions the kriya as a commodity, and survives to this day. The work of craft can still be found as complementary needs that can not be separated from human life. At home as the place we live (kitchen) can find a variety of kriya, such as: Aseupan (steamer), nyiru (nyiru), sieve etc. That happens in the past, now the term kriya has transformed its definitions. Kriya in the context of the past was understood as a work of art that is unique and its characteristic contains loads of aesthetic value, symbolic, philosophical, and functional as well as ngrawit in its making. The kriya in the present context has a different understanding; a branch of art activities; (1) can produce functional products with high craftmansif for economic and commercial interests, and (2) can also produce works of art that are an individual expression for the sake of artistic prestige.

In fact, kriya has a broad and general term that has many terms derived from it, such as: Art Kriya, Kriya-expression, Design Kriya, Kriya Design, Kriya Product, and Contemporary Kriya. These terms essentially be classified into two categories: kriya design and kriya art. The fundamental difference of these two categories lies in the motivation of the creation of its work. This can be explained that the design kriya activities always deal with the issue of the creation of functional objects for the commercial-economic interests, while the art craft activities is dealing with the creation of works of art purely for the sake of expression.

\section{References}

Asmujo. (2000). Dilema Pendidikan Kriya, dalam Refleksi Seni Rupa Indonesia Dulu Kini dan Esok.: Penyunting Baranul Anas penerbit Balai Pustaka.Jakarta.

Badudu, J. S. (2006). Kata-Kata Serapan BahasaAsing Dalam Bahasa Indonesia: Penerbit Buku Kompas, Jakarta.

Black, Hames A. dan Dean J. Champion. (1999). Motode dan Masalah Penelitian Sosial,: 


\section{Macrothink}

Journal of Social Science Studies

ISSN 2329-9150

2016, Vol. 3, No. 2

Penerbit Rafika Aditama, Bandung.

Gustami, S. P. (2009). Filosofi Seni Kria Tradisional Indonesia. Artikel: Majalah Seni Edisi XV.Jogjakarta.

Gustami, S. P. (2004). "Seni Kriya Indonesia Dilema Pembinaan dan Pengembangan", SENI: Jurnal Pengetahuan dan Pencitaan Seni. 1/03-14-II.

Prayitno, A. (2005). Dasar-dasar Pengembangan Desain: Balai Pustaka. Jakarta.

Sachari, A. (1989). Estetika Terapan, Spirit-spirit yang menikam Desain: Penerbit PT Nova. Bandung.

Sedyawati, E. (1999). Kria dalam Kebudayaan Indonesia: Makalah Kria dalam Konfrensi dan Pameran Rekayasa, Institut Teknologi Bandung.

Sckermerhorn, J. R. (2000). Hunt and Osborn, R.V, Managing Organizational Bahavior,: John Willeymd Son, New York.

Soegijo, S. (2009). Seni Kria dan Kerajinan Tangan,:Makalah Seminar Sehari Jakarta.

Yanagi, S. (1972). The Unknown Craftman Javanese Insight Inti Beauty: USA: Kodansa International.

Yudosaputro, W. (2003). Pengembangan Teknologi Anyam: Direktorat Pendidikan Menengah dan Kejuruan, Depdikbud. Bandung.

Yudosaputro, W. (2003). Perjalanan Seni Rupa Indonesia, Dari Zaman Prasejarah hingga Masa Kini: Pameran Seni Budaya. Bandung.

Yudosaputro, W. (1996). Seni Anyaman, Penerbit Craftman Malayasia: Kualalumpur.

\section{Copyright Disclaimer}

Copyright for this article is retained by the author(s), with first publication rights granted to the journal.

This is an open-access article distributed under the terms and conditions of the Creative Commons Attribution license (http://creativecommons.org/licenses/by/3.0/). 